\title{
ALLERGIC RHINITIS AND IMPORTANCE OF FEXOFENADINE HCL SUSTAINED RELEASE MICROSPHERE AS ITS TREATMENT APPROACH
}

\author{
PAROMA AREFIN ${ }^{*}$, MD SHEHAN HABIB ${ }^{1}$, NAZIM UDDIN AHMED ${ }^{2}$, MD ABDUR RAHIM ${ }^{2}$, MD IBRAHIM ${ }^{2}$, \\ SREEBASH CHANDRA BHATTACHARJEE ${ }^{1}$, DIPANKAR CHAKRABORTY ${ }^{1}$, SUMON DAS ${ }^{1}$, DEBABRATA \\ KARMAKAR ${ }^{1}$, DIP BHOWMIK ${ }^{1}$, SHIRMIN ISLAM ${ }^{3}$, MD SAIDUL AREFIN ${ }^{4}$
}

\author{
${ }^{1}$ Bangladesh Council of Scientific and Industrial Research (BCSIR) Laboratories, Chattogram, Bangladesh, ${ }^{2}$ Bangladesh Council of Scientific \\ and Industrial Research (BCSIR) Laboratories, Rajshahi, Bangladesh, ${ }^{3}$ Genetic Engineering and Biotechnology, Rajshahi University, \\ ${ }^{4}$ Institute of Nutrition and Food Science, University of Dhaka, Bangladesh \\ Email: paroma.arefin@gmail.com
}

Received: 24 Nov 2020, Revised and Accepted: 26 Nov 2021

\begin{abstract}
The current treatment approaches for allergic rhinitis are practiced over decades, but the patient quality of life has not yet changed so much. The reasons are research gaps in pathophysiology of the disease, proper management of the disease. Fexofenadine $\mathrm{HCl}$ is a second-generation antihistamine drug which has a half-life of about $14.4 \mathrm{~h}$. It is useful in the management of common symptoms like sneezing, itchy throat, and red eyes in individuals suffering from allergic rhinitis. Fexofenadine immediate release or sustained release formulations are available in the market as suspension, tablet and capsule. In this research paper, we have discussed the symptoms associated with allergic rhinitis and treatment approaches. Fexofenadine $\mathrm{HCl}$ is being used for the treatment of this disease. But as it has a long half-life, we have discussed the importance of the introduction of sustained-release microsphere formulation of Fexofenadine $\mathrm{HCl}$ in the market.
\end{abstract}

Keywords: Allergic rhinitis, Bioavailability, Fexofenadine $\mathrm{HCl}$, Microsphere, Second generation antihistamine

(c) 2022 The Authors. Published by Innovare Academic Sciences Pvt Ltd. This is an open access article under the CC BY license (https://creativecommons.org/licenses/by/4.0/) DOI: https://dx.doi.org/10.22159/ijap.2022v14i1.40369. Journal homepage: https://innovareacademics.in/journals/index.php/ijap

\section{INTRODUCTION}

Allergic rhinitis is one of the most common chronic conditions in the world [1-3]. Previously first-generation antihistamines were used for its management [4-6]. But due to sedative side effects, now second-generation antihistamines are being used. Fexofenadine $\mathrm{HCl}$ is a second generation antihistamine drug [7-10]. The dose of fexofenadine $\mathrm{HCl}$ is $60 \mathrm{mg}$ twice a day or $120 \mathrm{mg}$ once a day or 180 mg orally once a day for adults and children of $\geq 12 \mathrm{y}$. For children with 6-11 y, the recommended dose is $30 \mathrm{mg}$ twice daily. Fexofenadine is available in tablet or capsule form. Oral suspension is used for children with 6 mo or older with the recommended dose of $15 \mathrm{mg}$ twice for $6 \mathrm{mo}$ to $2 \mathrm{y}$ and $30 \mathrm{mg}$ for 2-11 y [11-14].

Due to their free-flowing properties and biodegradable existence, microparticles or microspheres have recently gained considerable interest, typically consisting of synthetic polymeric materials with particle size ranging between $1-1000 \mu \mathrm{m}[15,16]$. Besides, microspheres are useful for targeted release and sustained release of the drugs [17]. Other dosage forms, though giving sustained release of the drug but poses a risk of dose dumping [18]. Drugs with lower bioavailability would be excreted out from the body with low absorption with rest of the drugs unused and excreted [12,15]. So, the extra amount of drug is given to the body for reaching the minimum effective concentration (MIC) [19]. For chronic diseases, patients have to take a drug for long terms with the risk of possible side effects. On the other hand, drugs with low absorption and bioavailability are required to be administered to be high amount which is not cost-effective for manufactures and convenient for patients in respect of price and pharmacodynamics.

Fexofenadine $\mathrm{HCl}$ has low absorption (30-40\%) profile [16, 20]. So, microspheres dosage forms of Fexofenadine $\mathrm{HCl}$ is expected to be convenient to have the maximum use of the given dose with sustained effects. It would also help to avoid the dose dumping risks, and to decrease the cost for manufacturers and medication cost for patients [21]. We have explored the published research of last $20 \mathrm{y}$ to interpret the changes, advancement and limitation is the management of allergic rhinitis. We have accessed the pubmed databases, web of science and scopus databases for this search.

\begin{abstract}
Allergic rhinitis
Allergic rhinitis is a global health problem caused by IgE-mediated inflammation of the membranes covering the nose following allergen exposure $[1,22-24]$. It is mainly categorized as a symptomatic disease with 4 main symptoms such as anterior or posterior rhinorrhoea, sneezing, nasal itching, and nasal congestion $[1,7,22,25]$. Allergic rhinitis is an allergic response that occurs when the immune system reacts to the intake of foreign materials [26]. The symptoms are mild or sometimes serious. The symptoms usually mimic a cold as they include stuffy, runny nose, sneezing, dry cough, sore throat, headache, itchy mouth and throat, fatigue etc [ 1 , $7,13,23,26]$. There is also asthma in certain individuals who have allergic rhinitis $[1,27,28]$. Asthma is a persistent inflammatory airway behavior that leads to reversible obstruction of the airway and bronchial hyper-responsiveness to different stimuli, causing wheezing, breathlessness, chest tightness, and coughing symptoms [28-30]. Studies have shown that not treating allergic rhinitis contributes to higher costs and hospitalization for asthma $[2,7,23$, 24]. The onset of asthma can be avoided by early and active treatment of Allergic Rhinitis [2, 22, 25]. Seasonal allergic rhinitis, also known as hay fever and perennial allergic rhinitis, are the two main forms of allergic rhinitis [31]. Outdoor allergens are responsible for hay fever. Indoor allergens, including dust mites, pet dander, and moulds are liable for perennial allergic rhinitis [32]. Allergic Rhinitis is reported to affect $20-30 \%$ of adult people and $40 \%$ children in both of the USA and Europe [33].
\end{abstract}

\section{Causes of allergic rhinitis}

Inflammatory substances, including such histamine are produced by these cells that cause fluid to accumulate in the nasal tissues (congestion), itching, sneezing, and runny nose [22, 34]. These chemicals stimulate other inflammatory cells for many hours, which can cause persistent symptoms [25, 34, 35]. If an individual is allergic to something like a food or dust, the immune system mistakenly takes the foreign particle as harmful and responds to it accordingly. To defend them, the immune system sends the signal to the body to release histamine and other chemicals responsible for allergic reaction into the bloodstream [36, 37]. After release, histamine combines with the specific cellular Histamine receptor-H1 
receptor present on the cell membrane [32, 38]. H1 receptors are available on the cell membranes of smooth muscle of blood vessels, bronchial and intestinal muscle, endothelium, thalamus, hypothalamus and cerebellum parts of central nervous system [6, 39]. In many cases, the lymphocyte mediates the allergic response. The IgE molecule specific to an antigen binds to membrane receptors on mast cells. Antigen then triggers the mast cell to react. Often histamine is released in response [32, 36, 37].

Allergic rhinitis can be seasonal or perennial [2]. The allergens that most commonly cause seasonal allergic rhinitis include pollens from trees, grasses, and weeds, as well as spores from fungi and moulds [40]. Female counterparts are more susceptible to allergies and different age group also have a different level of severity in sufferings [41]. People having family history of allergies have more tendencies to have allergic rhinitis. Some people are allergic to specific kinds of food or protein items $[8,42]$.

\section{Treatment approaches}

Allergic rhinitis management should be a combined approach consisting avoidance of allergens, pharmacotherapy and immunotherapy. Drugs such as antihistamines, decongestants, and nasal corticosteroid sprays (INSs) are recommended therapies are recommended in a step-wise approach depending on the severity of the disorder. In patients with chronic allergic rhinitis, background, chest assessment and where appropriate, airflow obstruction evaluation before and after a bronchodilator should be treated for asthma. In patients with chronic rhinitis and serious intermittent rhinitis, follow-up is necessary [5, 28, 31, 38, 43].

Antihistamines are the most cost-effective treatment approach offering least level of complications [5, 6]. The oral steroids might be cost-effective but the limitation is a range of strong side effects [44, 45]. Sublingual immunotherapy was identified as the most costeffective immunotherapy and exhibits a good side-effect profile [25]. The differences between sublingual and subcutaneous immunotherapy are little. Antihistamines are reported to be the most cost-effective option of all therapies [39].

\section{Special consideration in treatment}

Rhinitis is a concern during pregnancy, as the pregnancy itself will aggravate nasal obstruction. As certain drugs cross the placenta, care must be taken when prescribing any drug during pregnancy $[46,47]$. Physiological changes arise with ageing in the connective tissue and nasal vasculature that are predisposed to chronic rhinitis. Though it is a common issue, but it is hard to manage atrophic rhinitis $[48,49]$. With anticholinergics, rhinorrhoea can be managed [50]. Rhinitis can also be caused by certain medications methyldopa, reserpine, guanethidine, phentolamine, prazosin, chlorpromazine or ACE inhibitors [1]. In elderly patients, certain medications can cause specific side effects $[1,34,38]$. Decongestants and anticholinergic drugs can lead to urinary retention in patients with prostatic hypertrophy [51, 52]. In childhood, allergic rhinitis is a commonly observed phenomenon in school days [1,53]. The treatment approaches for children are the same as with adults, but the side effects characteristic of this age group must be minimized with extra precautions [31,53]. Medication doses must be modified and special factors must be considered. Symptoms cognitive functioning and school results, which can be further affected by the use of oral H1antihistamines with sedation. Because of the efficacy of the medication, Disodium cromoglycate is widely used to treat allergic rhino-conjunctivitis in infants [53]. Immunotherapy also helps immune system get used to allergens through regular injections of small doses of an allergen over a long period of time [25].

\section{Antihistamines}

Antihistamines are agents which binds to the Histamine receptors (H1 receptor) and prevent Histamine to mediate allergic response $[5,6]$. The symptoms of Allergic rhinitis include nasal block, headache, daytime sleepiness etc. Allergic Rhinitis deteriorate the quality of patient's daily life and impact regular activities [5-7, 26, 30]. Ultimately working efficiency of the patient is reduced and life quality decreases.

Antihistamines are widely used in the treatment of allergic rhinitis. Sneezing, itching and watery rhinorrhea are especially cured by this class of drug $[39,54]$. Antihistamines come with two generations: first generation and second generation (table 1) $[2,9,23,55,56]$. Antihistamines belonging to first-generation class are less prescribed as they have poor selectivity and sedative, cardiovascular, and anticholinergic effects [9]. They block the $\mathrm{H}_{1}$ receptors and also antagonizes the effects by binding to muscarinic receptors (sedative), $\alpha$-adrenoceptors, serotonin receptor and local anaesthetic sites (Na-channel). In comparison with first-generation medications, second-generation antihistamines have a greater efficacy and longer time of action, with no or limited side effects [4]. Again, first generation antihistamines have sedative effects. So, they induce more need of sleep. Second generation antihistamines became popular to treat allergic rhinitis mostly due to their no sedative effects $[9,51,55,57]$.

Second generation antihistamines have fewer sedative effects which is common with the first-generation ones. $\mathrm{H}_{1}$ antagonists exert its effect by competitively and reversibly blocking the $\mathrm{H}_{1}$ receptor $[5,9$, 55]. They also do not have anti-cholinergic or anti-adrenergic or local anesthetic effect. First generation antihistamines can cross the BBB (Blood Brain Barrier) and produce central nervous effects (CNS). Newer versions of antihistamines do not enter the CNS [4]. Antihistamine drugs are well absorbed from gastrointestinal tract; peak plasma concentration is within $1-2 \mathrm{~h}$ and duration of action is 4-6 h. The $2^{\text {nd }}$ generation has long duration of action and they are completely metabolized from the liver by cytochrome P-450 enzyme $[5,9,55]$. They are excreted through urine. Second-generation antihistamines are less lipid-soluble and long duration of action so can be given once daily. H1-receptor antagonists are effective for the treatment of seasonal allergic rhinitis. But some second-generation H1-receptor antagonists prolong the corrected QT interval (QTc) and poses the threat to have ventricular arrhythmias $[1-4,8,12]$.

Table 1: Fexofenadine $\mathrm{HCl}$ generations

\begin{tabular}{ll}
\hline $\mathbf{1}^{\text {st Generation }}$ & 2nd Generation \\
\hline Ethanolamines, e. g. Carbinoxamine, Dimenhydrinate, Diphenhydramine, Doxylamine & Piperidines, e. g. Astemizol, Fexofenadine \\
Ethylaminediamines, e. g. Pyrilamine & [3, 6, 9, 39, \\
Piperazin derivatives, e. g. Hydroxyzine, Cyclizine, Meclizine & 55-58] \\
Alkylamines, e. g. Chlorpheniramine & \\
Phenothiazinederivatives, e. g. Promethazine(Phenergan) & \\
Miscellaneous, e. g. Cyproheptadine & \\
\hline
\end{tabular}

\section{Fexofenadine $\mathrm{HCl}$-a second-generation antihistamine}

Fexofenadine $\mathrm{HCl}$ is the carboxylic acid metabolite of terfenadine. It is a second-generation antihistamine [16]. Fexofenadine $\mathrm{HCl}$ does not cross the blood-brain barrier. So, it does not have any sedating side effects [15]. Fexofenadine is rapidly absorbed and has a long duration of action, making it suitable for once-daily administration [59]. It has been reported to have no sedating and electrocardiographic effects. It has been marketed and used in the
United States since 2000 [12]. Fexofenadine $\mathrm{HCl}$ is effective for the treatment of allergic rhinitis [20]. The available dosage forms are tablet, capsule and oral suspension. They have been proved to be bioequivalent.

Fexofenadine, the active metabolite of terfenadine, is a selective histamine $\mathrm{H} 1$ receptor antagonist that does not cross the bloodbrain barrier and appears to display some anti-inflammatory properties $[12,20]$. Fexofenadine is rapidly absorbed within two 
hours of ingestion and has a long duration of action (half-life 14.4 h), making it suitable for once daily administration. The dose of fexofenadine $\mathrm{HCl}$ is $60 \mathrm{mg}$ twice a day or $120 \mathrm{mg}$ once a day or 180 mg orally once a day for adults and children efl 2 y. For children with 6-11 $\mathrm{y}$, the recommended dose is $30 \mathrm{mg}$ twice daily. Oral suspension is used for children with 6 mo or older with recommended dose of $15 \mathrm{mg}$ twice for $6 \mathrm{mo}$ to $2 \mathrm{y}$ and $30 \mathrm{mg}$ for $2-11 \mathrm{y}$. Fexofenadine is similarly effective as loratadine or cetirizine in management of allergic rhinitis [60]. Fexofenadine $\mathrm{HCl}$ has been proved to improve quality of life more in comparison of loratadine [11].

Fexofenadine $60 \mathrm{mg}$ twice daily and $120 \mathrm{mg}$ once daily was reported to be as effective as loratadine $10 \mathrm{mg}$ once daily, and fexofenadine $120 \mathrm{mg}$ once daily was reported to be as effective as cetirizine $10 \mathrm{mg}$ once daily in reducing the sufferings of allergic rhinitis. Fexofenadine $\mathrm{HCl}$ and extended-release pseudoephedrine gives complementary effect if administered in combination [11,60]. Fexofenadine helps to get relief from most of the symptoms of allergic rhinitis $[13,20]$. The side effect of Fexofenadine treatment mostly reported, is headache. Fexofenadine is does not cause prolongation of the corrected QT interval like terfenadine. When given alone or in combination with erythromycin or ketoconazole, it showed no adverse cardiac events [12, 13, 20,59].

\section{Fexofenadine $\mathrm{HCl}$ as microsphere dosage form}

Researchers are suggesting the intranasal corticosteroids (INCS) due to its greater efficacy over antihistamines. But in the perspective of safety, antihistamines are more accepted globally [5, 61, 62]. So, this is chosen as the first-line therapy. INCS have another limitation of longer onset of action. Allergen immunotherapy by subcutaneous or sublingual route is the disease-modifying option [63-68]. But in subcutaneous route, immunotherapy requires additional challenging management approaches though the sublingual route is safer than the subcutaneous route $[23,45,47,63,66,69,70]$. All of these options are indicated only for lower efficacy of antihistamines [14, 70]. For allergic rhinitis, the most commonly recommended antihistamine drug is Fexofenadine $\mathrm{HCl}$. Fexofenadine $\mathrm{HCl}$ has a halflife of $14.4 \mathrm{~h}[15,16]$. To make the drug dose convenient for patients, it has also been marketed as sustained release dosage form of tablet or capsule. Microspheres serve to improve dosage efficiency while minimizing the potential side effects. The microspheres of active pharmaceutical ingredients (API) enable pharmaceutical companies to engineer release profiles most appropriately. Fexofenadine $\mathrm{HCl}$ loaded polymeric microspheres can help to get desired absorption profile and better bioavailability. Besides microspheres provide high margin of safety as it removes the probability of dose burst. In case of Fexofenadine $\mathrm{HCl}, 30-40 \%$ drug is absorbed $[15,16]$. The rest is excreted without absorption through kidney. If Fexofenadine $\mathrm{HCl}$ sustained release microspheres of polymer blends are used, the side effects would be reduced as less drug is given, kidney would clear off less drug. the required dose could be delivered to patient on basis of individual requirement, pathophysiology and body condition. The required dose in microspheres can also be delivered in capsule form and the required dose could be calculated on the basis of drug entrapment efficiency and drug loading of the microsphere. It would also help to reduce the cost of production as less amount of the drug is required to incorporate into the dosage form. As a result, the patients would be able to get the medications in lower price. The polymer content should be kept in a low range for balancing its long half-life and low absorption. Ultimately total dose may be reduced with greater bioavailability.

\section{CONCLUSION}

Allergic rhinitis is a global problem and it is not curable completely. Proper treatment approaches can help the patient to get an improved quality of life. In the world of comorbidities, the researchers are continuously trying to find out ways to reduce the side effects of drug by modifying the molecule, site-specific targeted release of the drug, dosage forms. Besides we also focus on increasing the costeffectiveness of medications. The intranasal corticosteroids (INCS), subcutaneous and sublingual immunotherapy have been proposed as recent management approaches due to the lower efficacy of Fexofenadine $\mathrm{HCl}$, i.e. its lower bioavailability. Fexofenadine $\mathrm{HCl}$ is a long-term drug and primary choice for patients with Allergic Rhinitis.
If we can obtain greater efficacy by increasing bioavailability by preparing optimized sustained-release microspheres, it could be a great option in all respects: convenience, cost-effectiveness, high margin of safety for patients.

\section{FUNDING}

Nil

\section{AUTHORS CONTRIBUTIONS}

All authors have contributed equally.

\section{CONFLICT OF INTERESTS}

This research has no conflict of interest.

\section{REFERENCES}

1. Varshney J, Varshney H. Allergic rhinitis: an overview. Indian J Otolaryngol Head Neck Surg. 2015;67(2):143-9. doi: 10.1007/s12070-015-0828-5, PMID 26075169.

2. Liang $M, X u R, X u$ G. Recent advances in allergic rhinitis. Lin Chung Er Bi Yan Hou Tou Jing Wai Ke Za Zhi. 2015;29(3):202-6. PMID 26012287.

3. Oral antihistamines for allergic disorders. Drug Ther Bull. 2002 Aug;40(8):59-62. doi: 10.1136/dtb.2002.40859, PMID 12216338.

4. Fein MN, Fischer DA, O'Keefe AW, Sussman GL. CSACI position statement: newer generation H1-antihistamines are safer than first-generation H1-antihistamines and should be the first-line antihistamines for the treatment of allergic rhinitis and urticaria. Allergy Asthma Clin Immunol. 2019;15(1):61. doi: 10.1186/s13223-019-0375-9, PMID 31582993.

5. Church MK, Church DS. Pharmacology of antihistamines. Indian J Dermatol. 2013;58(3):219-24. doi: 10.4103/00195154.110832, PMID 23723474.

6. Simons FER, Simons KJ. H1 antihistamines: current status and future directions. World Allergy Organ J. 2008;1(9):145-55. doi: 10.1186/1939-4551-1-9-145, PMID 23282578.

7. $\mathrm{Hu} \mathrm{Y}$, Sieck DE, Hsu WH. Why are second-generation H1antihistamines minimally sedating? Eur J Pharmacol. 2015 Oct;765:100-6. doi: 10.1016/j.ejphar.2015.08.016, PMID 26291661.

8. Slater JW, Zechnich AD, Haxby DG. Second-generation antihistamines: a comparative review. Drugs. 1999;57(1):31-47. doi: 10.2165/00003495-199957010-00004, PMID 9951950.

9. Small P, Keith PK, Kim H. Allergic rhinitis. Allergy Asthma Clin Immunol. 2018;14(Suppl 2):51. doi: 10.1186/s13223-0180280-7, PMID 30263033.

10. Sur DK, Scandale S. Treatment of allergic rhinitis. Am Fam Physician. 2010;81(12):1440-6. PMID 20540482.

11. Axelrod D, Bielory L. Fexofenadine hydrochloride in the treatment of allergic disease: a review. J Asthma Allergy. 2008 Sep;1:19-29. doi: 10.2147/jaa.s3092, PMID 21436982.

12. Simpson K, Jarvis B. Fexofenadine: a review of its use in the management of seasonal allergic rhinitis and chronic idiopathic urticaria. Drugs. 2000 Feb;59(2):301-21. doi: 10.2165/ 00003495-200059020-00020, PMID 10730552.

13. Meltzer EO, Casale TB, Nathan RA, Thompson AK. Once-daily fexofenadine $\mathrm{HCl}$ improves the quality of life and reduces work and activity impairment in patients with seasonal allergic rhinitis. Ann Allergy Asthma Immunol. 1999 Oct;83(4):311-7. doi: 10.1016/S1081-1206(10)62671-3, PMID 10541423.

14. Moinuddin R, DeTineo M, Maleckar B, Naclerio RM, Baroody FM. Comparison of the combinations of fexofenadinepseudoephedrine and loratadine-montelukast in the treatment of seasonal allergic rhinitis. Ann Allergy Asthma Immunol. 2004 Jan;92(1):73-9. doi: 10.1016/S1081-1206(10)61713-9, PMID 14756468.

15. Arefin P, Hasan I, Islam MS, Reza MS. Formulation and in vitro evaluation of Eudragit RL 100 loaded fexofenadine $\mathrm{HCl}$ microspheres. Bangla Pharma J. 2016 Aug;19(1):58-67. doi: 10.3329/bpj.v19i1.29240.

16. Arefin P, Hasan I, Reza MS. Design, characterization and in vitro evaluation of HPMC K100 M CR loaded fexofenadine $\mathrm{HCl}$ microspheres. Springerplus. 2016 Dec;5(1). doi: 10.1186/s40064-016-2322-2. 
17. Das MK, Ahmed AB, Saha D. Microsphere a drug delivery system-A review. Int J Curr Pharm Sci. 2019 Jul:34-41. doi: 10.22159/ijcpr.2019v11i4.34941.

18. Chauhan A, Sagar MK, Kumar S, Sharma A. Formulation and evaluation of sustained-release microsphere for oral bioavailability enhancement of. Crit Rev. 2020;7(18):3057-70.

19. Gandra S. Enhanced intestinal absorption and bioavailability via proniosomes for Bazedoxifene acetate drug. Int J Pharm Pharm Sci. 2020 Nov;12(12):31-42. doi: 10.22159/ijpps.2020v12i12.39576.

20. Bernstein DI, Schoenwetter WF, Nathan RA, Storms W, Ahlbrandt R, Mason J. Efficacy and safety of fexofenadine hydrochloride for treatment of seasonal allergic rhinitis. Ann Allergy Asthma Immunol. 1997 Nov;79(5):443-8. doi: 10.1016/S1081-1206(10)63041-4, PMID 9396979.

21. Boyarchuk 0. Allergic manifestations of primary immunodeficiency diseases and its treatment approaches. Asian J Pharm Clin Res. 2018 Nov;11(11):83. doi: 10.22159/ajpcr.2018.v11i11.29059.

22. Bjermer L, Westman M, Holmström M, Wickman MC. The complex pathophysiology of allergic rhinitis: scientific rationale for the development of an alternative treatment option. Allergy Asthma Clin Immunol. 2019;15(1):24. doi: 10.1186/s13223-018-0314-1, PMID 31015846.

23. Titulaer J, Arefian H, Hartmann M, Younis MZ, Guntinas-Lichius O. Cost-effectiveness of allergic rhinitis treatment: an exploratory study. SAGE Open Med. 2018;6:2050312118794588. doi: 10.1177/2050312118794588, PMID 30147935.

24. Ciprandi G, Cosentino C, Milanese M, Mondino C, Canonica GW. Fexofenadine reduces nasal congestion in perennial allergic rhinitis. Allergy. 2001 Nov;56(11):1068-70. doi: 10.1034/j.1398-9995.2001.00191.x, PMID 11703220.

25. Oktemer T, Altintoprak N, Muluk NB, Senturk M, Kar M, Ali Bafaqeeh S, Bellussi L, Passali D, Cingi C. Clinical efficacy of immunotherapy in allergic rhinitis. Am J Rhinol-Allergy. 2016 Sep;30(5Suppl):S4-7. doi: 10.2500/ajra.2016.30.4368.

26. Bernstein JA. Allergic and mixed rhinitis: epidemiology and natural history. Allergy Asthma Proc. 2010;31(5):365-9. doi: 10.2500/aap.2010.31.3380, PMID 20929601.

27. Arefin P, Arefin MS, Arefin A. A review on the ayurvedic management of causes and symptoms of bronchial asthma. ASA Univ Rev. 2015;9(2):269-76.

28. Kim H, Bouchard J, Renzi PM. The link between allergic rhinitis and asthma: A role for antileukotrienes? Can Respir J. 2008;15(2):91-8. doi: 10.1155/2008/416095, PMID 18354749.

29. Meltzer EO. Role for cysteinyl leukotriene receptor antagonist therapy in asthma and their potential role in allergic rhinitis based on the concept of "one linked airway disease" Ann Allergy Asthma Immunol. 2000 Feb;84(2):176-85; quiz 185. doi: 10.1016/S1081-1206(10)62750-0, PMID 10719774.

30. Skoner DP. Allergic rhinitis: definition, epidemiology, pathophysiology, detection, and diagnosis. J Allergy Clin Immunol. $2001 \quad$ Jul;108(1);Suppl:S2-8. doi: 10.1067/mai.2001.115569, PMID 11449200.

31. Almehizia AA, AlEssa RK, Alwusaidi KM, Alzamil KA, AlJumah M, Aljohani S, Almutairi AF, Salam M. Allergic rhinitis: disease characteristics and coping measures in Saudi Arabia. PLOS ONE. 2019 Jun;14(6):e0217182. doi: 10.1371/journal.pone.0217182, PMID 31242201.

32. Weber RW. Allergic rhinitis. Prim Care Clin Off Pract. 2008 Mar;35(1):1-10. doi: 10.1016/j.pop.2007.09.001.

33. Srivastava R, Srivastava S, Singh SP. Thermoreversible in-situ nasal gel formulations and their pharmaceutical evaluation for the treatment of allergic rhinitis containing extracts of Moringa olifera and Embelia ribes. Int J Appl Pharm. 2017 Nov;9(6):16. doi: 10.22159/ijap.2017v9i6.18780.

34. Baraniuk JN. Pathogenesis of allergic rhinitis. J Allergy Clin Immunol. 1997;99(2):S763-72. doi 10.1016/s00916749(97)70125-8. PMID 9042069.

35. Rondon C, Campo P, Togias A, Fokkens WJ, Durham SR, Powe DG, Mullol J, Blanca M. Local allergic rhinitis: concept, pathophysiology, and management. J Allergy Clin Immunol. 2012;129(6):1460-7. doi: 10.1016/j.jaci.2012.02.032, PMID 22516477.
36. Taylor Clark T. Histamine in allergic rhinitis. Adv Exp Med Biol. 2010;709:33-41. doi: 10.1007/978-1-4419-8056-4_4, PMID 21618885

37. Naclerio RM. The role of histamine in allergic rhinitis. J Allergy Clin Immunol. 1990 Oct;86(4 Pt 2):628-32. doi 10.1016/s0091-6749(05)80227-1, PMID 1977783.

38. Rosenwasser LJ. Treatment of allergic rhinitis. Am J Med. 2002 Dec; 113(9);Suppl 9A:17-2417S-24S. doi: 10.1016/s00029343(02)01433-x, PMID 12517578.

39. Simons FER, Simons KJ. Histamine and H1-antihistamines: celebrating a century of progress. J Allergy Clin Immunol. 2011;128(6):1139-50. doi: 10.1016/j.jaci.2011.09.005, PMID 22035879.

40. Bousquet J, Khaltaev N, Cruz AA, Denburg J, Fokkens WJ, Togias A, Zuberbier T, Baena-Cagnani CE, Canonica GW, van Weel C, Agache I, Aït-Khaled N, Bachert C, Blaiss MS, Bonini S, Boulet LP, Bousquet PJ, Camargos P, Carlsen KH, Chen Y, Custovic A, Dahl R, Demoly P, Douagui H, Durham SR, van Wijk RG, Kalayci O, Kaliner MA, Kim YY, Kowalski ML, Kuna P, Le LT, Lemiere C, Li J, Lockey RF, Mavale-Manuel S, Meltzer EO, Mohammad Y, Mullol J, Naclerio R, O'Hehir RE, Ohta K, Ouedraogo S, Palkonen S, Papadopoulos N, Passalacqua G, Pawankar R, Popov TA, Rabe KF, Rosado-Pinto J, Scadding GK, Simons FE, Toskala E, Valovirta E, van Cauwenberge P, Wang DY, Wickman M, Yawn BP, Yorgancioglu A, Yusuf OM, Zar H, Annesi-Maesano I, Bateman ED, Ben Kheder A, Boakye DA, Bouchard J, Burney P, Busse WW, Chan-Yeung M, Chavannes NH, Chuchalin A, Dolen WK, Emuzyte R, Grouse L, Humbert M, Jackson C, Johnston SL, Keith PK, Kemp JP, Klossek JM, Larenas Linnemann D, Lipworth B, Malo JL, Marshall GD, Naspitz C, Nekam K, Niggemann B, Nizankowska Mogilnicka E, Okamoto Y, Orru MP, Potter P, Price D, Stoloff SW, Vandenplas O, Viegi G, Williams D, World Health Organization, GA(2)LEN, AllerGen. Allergic Rhinitis and its Impact on Asthma (ARIA) 2008 update (in collaboration with the World Health Organization, GA(2)LEN and AllerGen) Allergy. 2008 Apr; 63Suppl 86:8-160. doi: 10.1111/j.13989995.2007.01620.x, PMID 18331513.

41. Larsson U, Taft C, Karlsson J, Sullivan M. Gender and age differences in the relative burden of rhinitis and asthma on health-related quality of life-A Swedish population study. Respir Med. 2007 Jun; 101(6):1291-8. doi 10.1016/j.rmed.2006.10.014, PMID 17150347.

42. Nyenhuis SM, Mathur SK. Rhinitis in older adults. Curr Allergy Asthma Rep. 2013;13(2):171-7. doi: 10.1007/s11882-0130342-3, PMID 23389558

43. Maeda T, Babazono A, Nishi T. Surveillance of first-generation H1-antihistamine use for older patients with dementia in Japan: A retrospective cohort study. Curr Gerontol Geriatr Res. 2018 Jul;2018:1-63406210. doi: 10.1155/2018/3406210, PMID 30065759.

44. Petersen TH, Agertoft L. Corticosteroids for allergic rhinitis. Curr Treat Options Allergy. 2016;3(1):18-30. doi: 10.1007/s40521-016-0075-3.

45. Hox V, Lourijsen E, Jordens A, Aasbjerg K, Agache I, Alobid I, Bachert C, Boussery K, Campo P, Fokkens W, Hellings P, Hopkins C, Klimek L, Makela M, Mosges R, Mullol J, Pujols L, Rondon C, Rudenko M, Toppila Salmi S, Scadding G, Scheire S, Tomazic PV, Van Zele T, Wagemann M, van Boven JFM, Gevaert P. Benefits and harm of systemic steroids for short- and longterm use in rhinitis and rhinosinusitis: an EAACI position paper. Clin Transl Allergy. 2020;10(1):1-271. doi: 10.1186/s13601-019-0303-6, PMID 31908763.

46. Mazzotta P, Loebstein R, Koren G. Treating allergic rhinitis in pregnancy. Safety considerations. Drug Saf. 1999;20(4):361-75. doi: 10.2165/00002018-199920040-00005, PMID 10230583.

47. Khan NU, Begum KS. Allergic rhinitis during pregnancy-an update of management. Med Today. 2017;28(2):83-8. doi: 10.3329/medtoday.v28i2.32933.

48. Slavin RG. Treating rhinitis in the older population: special considerations. Allergy, Asthma Clin Immunol. 2009;5(1):14:9. doi: 10.1186/1710-1492-5-9, PMID 20016692.

49. Pinto JM, Jeswani S. Rhinitis in the geriatric population. Allergy, Asthma Clin Immunol. 2010;6(1):1-12:10. doi: 10.1186/17101492-6-10, PMID 20465792. 
50. Naclerio R. Anticholinergic drugs in nonallergic rhinitis. World Allergy Organ J. 2009;2(8):162-5. doi: 10.1097/WOX.0b013e3181b35336, PMID 24228813.

51. Serlin DC, Heidelbaugh JJ, Stoffel JT. Urinary retention in adults: evaluation and initial management. Am Fam Physician. 2018;98(8):496-503. PMID 30277739.

52. Verhamme KMC, Sturkenboom MCJM, Stricker BHC, Bosch R. Drug-induced urinary retention: incidence, management and prevention. Drug Saf. 2008;31(5):373-88. doi: 10.2165/00002018-200831050-00002, PMID 18422378.

53. Mir E, Panjabi C, Shah A. Impact of allergic rhinitis in school going children. Asia Pac Allergy. 2012;2(2):93-100. doi: 10.5415/apallergy.2012.2.2.93, PMID 22701858.

54. Muether PS, Gwaltney Jr JM. Variant effect of first- and second-generation antihistamines as clues to their mechanism of action on the sneeze reflex in the common cold. Clin Infect Dis. 2001 Nov;33(9):1483-8. doi: 10.1086/322518, PMID 11588693.

55. Randall KL, Hawkins CA. Antihistamines and allergy. Aust Prescr. 2018;41(2):42-541-5. doi: 10.18773/ austprescr.2018.013, PMID 29670310.

56. Ozdemir PG, Karadag AS, Selvi Y, Boysan M, Bilgili SG, Aydin A, Onder S. Assessment of the effects of antihistamine drugs on mood, sleep quality, sleepiness, and dream anxiety. Int J Psychiatry Clin Pract. 2014 Aug;18(3):161-8. doi: 10.3109/13651501.2014.907919, PMID 24673474.

57. Shasho H, Sakur AA, Trefi S. Eparation and assay of four antihistamine drugs diphenhydramine, chlorpheniramine, cyproheptadine and fexofenadine in pharmaceutical forms by a single HPLC method. Int J Pharm Pharm Sci. 2018 Apr; 10(4):53. doi: 10.22159/ijpps.2018v10i4.24819.

58. Kaiser HB, Rooklin A, Spangler D, Capano D. Efficacy of loratadine compared with fexofenadine or placebo for the treatment of seasonal allergic rhinitis. Clin Drug Investig. 2001;21(8):571-8. doi: 10.2165/00044011-200121080-00006.

59. Okubo K, Suzuki T, Tanaka A, Aoki H. Efficacy and safety of rupatadine in Japanese patients with seasonal allergic rhinitis: A double-blind, randomized, multicenter, placebo-controlled clinical trial. Allergol Int. 2019 Apr;68(2):207-15. doi: 10.1016/j.alit.2018.08.011, PMID 30391169.

60. Juel Berg N, Darling P, Bolvig J, Foss Skiftesvik MH, Halken S, Winther L, Hansen KS, Askjaer N, Heegaard S, Madsen AR, Opstrup MS. Intranasal corticosteroids compared with oral antihistamines in allergic rhinitis: A systematic review and meta-analysis. Am J Rhinol Allergy. 2017 Jan;31(1):e19-281928. doi: 10.2500/ajra.2016.30.4397, PMID 28234147.

61. Ortiz AS, McMains KC, Laury AM. Single vs multiallergen sublingual immunotherapy in the polysensitized patient: a pilot study. Int Forum Allergy Rhinol. 2018 Apr;8(4):490-4. doi: 10.1002/alr.22071, PMID 29377605.

62. Valovirta E, Petersen TH, Piotrowska T, Laursen MK, Andersen JS, Sørensen HF, Klink R, GAP investigators. Results from the 5year SQ grass sublingual immunotherapy tablet asthma prevention (GAP) trial in children with grass pollen allergy. J Allergy Clin Immunol. 2018 Feb;141(2):529-38. doi: 10.1016/j.jaci.2017.06.014, PMID 28689794.
63. Pajno GB, Bernardini R, Peroni D, Arasi S, Martelli A, Landi M, Passalacqua G, Muraro A, La Grutta S, Fiocchi A, Indinnimeo L, Caffarelli C, Calamelli E, Comberiati P, Duse M, Allergen-specific immunotherapy panel of the italian society of pediatric allergy and immunology (SIAIP). Clinical practice recommendations for allergen-specific immunotherapy in children: the Italian consensus report. Ital J Pediatr. 2017 Dec;43(1):13. doi: 10.1186/s13052-016-0315-y, PMID 28257631.

64. Yonekura S, Gotoh M, Kaneko S, Kanazawa K, Takeuji Y, Okubo $\mathrm{K}$, Okamoto Y. Treatment duration-dependent efficacy of Japanese cedar pollen sublingual immunotherapy: evaluation of a phase II/III trial over three pollen dispersal seasons. Allergol Int. 2019 Oct;68(4):494-505. doi: 10.1016/j.alit.2019.05.002, PMID 31257168.

65. Sayed KM, Kamel AG, Ali AH. One-year evaluation of clinical and immunological efficacy and safety of sublingual versus subcutaneous allergen immunotherapy in allergic conjunctivitis. Graefe's Arch Clin Exp Ophthalmol. 2019 Sep;257(9):1989-96. doi: 10.1007/s00417-019-04389-w, PMID 31209565.

66. Moote W, Kim H, Ellis AK. Allergen-specific immunotherapy. Allergy, Asthma Clin Immunol. 2018 Sep;14(Suppl 2):53. doi: 10.1186/s13223-018-0282-5, PMID 30275845.

67. Bernstein DI, Bardelas JA, Svanholm Fogh B, Kaur A, Li Z, Nolte $\mathrm{H}$. A practical guide to the sublingual immunotherapy tablet adverse event profile: implications for clinical practice. Postgrad Med. 2017 Aug;129(6):590-7. doi: 10.1080/00325481.2017.1302306, PMID 28326906.

68. Ellis AK, Gagnon R, Hammarby E, Lau A. Sublingual immunotherapy tablet for the treatment of house dust mite allergic rhinitis in Canada: an alternative to minimize treatment costs? Allergy, Asthma Clin Immunol. 2019 Dec;15(1):27. doi: 10.1186/s13223-019-0344-3, PMID 31061666.

69. Hossenbaccus L, Linton S, Garvey S, Ellis AK. Towards definitive management of allergic rhinitis: best use of new and established therapies. Allergy, Asthma Clin Immunol. 2020 Dec;16(1):39. doi: 10.1186/s13223-020-00436-y, PMID 32508939.

70. Brozek JL, Bousquet J, Agache I, Agarwal A, Bachert C, Bosnic Anticevich S, Brignardello-Petersen R, Canonica GW, Casale T, Chavannes NH, Correia de Sousa J, Cruz AA, Cuello-Garcia CA, Demoly P, Dykewicz M, Etxeandia-Ikobaltzeta I, Florez ID, Fokkens W, Fonseca J, Hellings PW, Klimek L, Kowalski S, Kuna $\mathrm{P}$, Laisaar KT, Larenas-Linnemann DE, Lødrup Carlsen KC, Manning PJ, Meltzer E, Mullol J, Muraro A, O’Hehir R, Ohta K, Panzner P, Papadopoulos N, Park HS, Passalacqua G, Pawankar R, Price D, Riva JJ, Roldan Y, Ryan D, Sadeghirad B, Samolinski B, Schmid-Grendelmeier P, Sheikh A, Togias A, Valero A, Valiulis A, Valovirta E, Ventresca M, Wallace D, Waserman S, Wickman M, Wiercioch W, Yepes Nunez JJ, Zhang L, Zhang Y, Zidarn M, Zuberbier T, Schünemann HJ. Allergic Rhinitis and its Impact on Asthma (ARIA) guidelines-2016 revision. J Allergy Clin Immunol. 2017 Oct;140(4):950-8. doi: 10.1016/ j.jaci.2017.03.050, PMID 28602936. 